Publisher: Faculty of Agronomy Čačak

\title{
Nutritional attributes of wheat bread fortified with convectively dried chokeberry powder
}

\author{
Vladimir Filipović1, ${ }^{*}$, Marko Petković2 , Jelena Filipovićs ${ }^{3}$ Igor Đurović4, Nemanja Miletić2, \\ Jovana Radovanović ${ }^{2}$ Ivana Filipović ${ }^{5}$ \\ ${ }^{1}$ Department of Chemical Engineering , Faculty of Technology, University of Novi Sad, Bulevar Cara Lazara 1, 21102 Novi \\ Sad, Serbia \\ 2 Department of Food Technology, Faculty of Agronomy Čačak, University of Kragujevac, Cara Dušana 34, 32102 Čačak, \\ Serbia \\ 3 Institute for Food Technology, University of Novi Sad, Bulevar cara Lazara 1, 21101 Novi Sad, Serbia \\ 4 Department of Chemistry and Chemical Engineering, Faculty of Agronomy Čačak, University of Kragujevac, Cara \\ Dušana 34, 32102 Čačak, Serbia \\ 5 SP Laboratory, Industrijska 3, 21220 Bečej, Serbia
}

*Corresponding author: vladaf@uns.ac.rs

Received 8 December2020; Accepted 5 May 2021

\begin{abstract}
A B S T R A C T
Chokeberry (Aronia melanocarpa L.) has a positive effect on human health, and therefore it can be used as a beneficial component for food (e.g. wheat bread) fortification. Dried chokeberry powder (CP), obtained by convective drying at 50,60 , and $70^{\circ} \mathrm{C}$, fortified bread samples by replacing wheat flour at levels of 1, 2.5, 5 and 10\%. Bread samples fortified with chokeberry were characterized by a decrease in total starch and protein contents and an increase in total sugar, mineral $(\mathrm{Mg}, \mathrm{Ca}, \mathrm{Cu})$, and fat components; unsaturated oleic acid was reduced, unlike unsaturated linoleic and linolenic acids. All developed mathematical models for starch, protein, fat, and minerals in bread supplemented with $\mathrm{CP}$ were characterized by statistically insignificant residual variances and high values of $\mathrm{R}^{2}$. Z-score analysis showed the optimal segment and total scores of bread fortified with $\mathrm{CP}$. Chokeberries dried at a temperature of $60^{\circ} \mathrm{C}$ showed the best nutritional attributes. Wheat bread enriched with $\mathrm{CP}$ in the amount of $10 \%$ had the highest level of fortification.
\end{abstract}

Keywords: chokeberry, bread, fortification, nutrition, Z-score.

\section{И 3 В О д}

Aронија (Aronia melanocapra L.) има позитиван ефекат на људско здравље, тако да би се могла третирати као корисна сировина за обогаћивање тј. фортификацију хране (нпр. пшеничног хлеба). Сушени прах ароније (ПА), добијен конвективним сушењем ароније на 50,60 и $70^{\circ} \mathrm{C}$, обогатио је хлеб заменом дела пшеничног брашна у количини од $1,2.5$, 5 и 10\%. Обогаћени хлеб са додатком ароније показује смањење укупног скроба и протеина и повећање укупних шећера, минерала $(\mathrm{Mg}, \mathrm{Ca}, \mathrm{Cu})$ и масти; незасићена олеинска киселина је смањена, за разлику од незасићених - линолне и линоленске киселине. Све развијене математичке моделе хемијског састава (садржаја скроба, протеина и масти) и садржаја минерала хлеба са додатом ПА карактерисале су статистички безначајне резидуалне варијансе и високе вредности $\mathrm{R}^{2}$. Примењена Z-Score анализа показала је оптималну сегментну и укупну оцену узорака хлебова са додатком ПА. Аронија сушена на температури од $60^{\circ} \mathrm{C}$ показала је најбоље нутритивне особине. Пшенични хлеб обогаћен ПА у количини од $10 \%$ имао је највиши ниво обогаћења.

Кључне речи: аронија, хлеб, фортификација, нутритивне особине, Z-Score анализа.

\section{Introduction}

Chokeberry, as well as chokeberry pomace (especially seed-rich pomace), contains saccharides (2.7-3.5 mg $100 \mathrm{mg}^{-1} \mathrm{DW}$ ), proteins (18-24 mg 100 $\mathrm{mg}^{-1} \mathrm{DW}$ ), and lipids (9.8-13.9 mg $\left.100 \mathrm{mg}^{-1} \mathrm{DW}\right)$ with high levels of unsaturated fatty acids (Dulf et al., 2012, Sójka et al., 2013). The most dominant sugars in chokeberry were sorbitol (6.55-12.99 g $\left.100 \mathrm{~g}^{-1} \mathrm{FW}\right)$, glucose (1.53-3.02 g $\left.100 \mathrm{~g}^{-1} \mathrm{FW}\right)$, sucrose $(0.06-0.41 \mathrm{~g}$ $\left.100 \mathrm{~g}^{-1} \mathrm{FW}\right)$, and fructose $\left(2.2-3.69 \mathrm{~g}^{\left.100 \mathrm{~g}^{-1} \mathrm{FW}\right)}\right.$ (Denev et al., 2018).
In general, berries are a rich source of macro-and microelements (Kulling and Rawel, 2008, Nile and Park, 2014, Šnebergrová et al., 2014). Chokeberries and their by-products are an excellent dietary source of minerals (especially $\mathrm{Ca}, \mathrm{K}$, and $\mathrm{Mg}$ ), and organic compounds (Juranović-Cindric et al., 2017). The mineral content of fresh berries varied between $440 \mathrm{mg} 100 \mathrm{~g}^{-1}$ and 580 mg $100 \mathrm{~g}^{-1}$ (Tanaka and Tanaka, 2001, Scott and Skirvin, 2007).

The total fat content in fresh chokeberry fruit was 0.09-0.17\%. In chokeberry pomace, the content was $5.5 \mathrm{~g} 100 \mathrm{~g}^{-1}$, including $65.0 \%$ of polyunsaturated fatty acids. The most considerable fat amounts were found in 
seed and skin fractions, $13.9 \%$ and $2.9-9.8 \%$, respectively [Sójka et al., 2013]. Chokeberry pomace mostly contained unsaturated fatty acids, i.e. linoleic and oleic acids (Zlatanov, 1999; Tanaka and Tanaka 2001; Sidor and Gramza-Michałowska, 2019). Factors such as cultivar, soil, climate conditions, and fertilization of chokeberry fruit and wheat might influence the minerals available in fruit powder and flour and, consequently, in their ash content. Fruit powder (fruit flour) is rich in minerals and has high water and oil holding capacity, which categorizes it as a low-calorie product (Ferreira et al., 2013; Eshak, 2016).

The range of functional ingredients of bread can be expanded and enlarged by replacing a portion of wheat flour with chokeberry fruit powder. In this way, a functional fortified product with a specific aroma and a slightly acidic taste is obtained. Generally, bread is the principal food in many countries, and many wheat flour alternatives in yeast-leavened bread making have been exploited recently (Filipović et al., 2006, Bhol et al., 2015). New functional bakery products are enriched with a high amount of bioactive compounds and dietary fibers (Motta et al., 2019). Chokeberry powder could be used to make bread from wheat flour in an amount of 1 to $5 \%$ by weight of flour, keeping their sensory and physicochemical quality characteristics. The optimum doses of black chokeberry powder in muffins were up to $10 \%$ (Parshutina et al., 2012). One way to use chokeberry powder was to produce indented shortbread cookies containing $8.7 \%$ of the powder. The resulting products were highly nutritious and calorific, with a wide range of bioactive components (minerals, vitamins, pectins, etc.), which could neutralize toxins formed from intestinal activity, and bind and remove heavy metal salts from the body (Kurtskova, 2005). In wheat flour of standard quality, adding $5 \%$ of chokeberry powder increases the mechanical strength of pasta by $20 \%$. Other quality parameters, including cooking characteristics, are within permissible limits (Koshak and Pokrashinskaya, 2020).

Since chokeberry powder has a rich chemical composition, it could be used to fortify flour-based foods. The specific objective of this study was to determine and optimize the effects of wheat flour supplementation with chokeberry powder $(1,2.5,5$, $10 \%$ ), obtained by convective drying at different temperatures $\left(50,60\right.$, and $\left.70^{\circ} \mathrm{C}\right)$, on the nutritional characteristics of bread samples. The results presented could serve as an essential parameter for global food nutrient fortification.

\section{Materials and methods}

\subsection{Materials}

Black chokeberry fruits (black aronia, Aronia melanocarpa L.) were collected at the location of the village of Kušići, Javor mountain: $43^{\circ} 28^{\prime} 40.8^{\prime \prime} \mathrm{N}$, $20^{\circ} 03^{\prime} 35.7$ "E, Republic of Serbia. Dehydration by a convective method was performed in a dehydrator (Colossus CSS 5330, PRC), at temperatures of 50, 60, and $70^{\circ} \mathrm{C}$, at atmospheric pressure and at a constant hot air velocity of $3 \mathrm{~m} \mathrm{~s}^{-1}$, to constant weight. Dried chokeberries were ground in a grinder (Delimano Chopper, Switzerland, $200 \mathrm{~W} / 50 \mathrm{~Hz}$ ), and sieved (sieve diameter $<0,5 \mathrm{~mm}$ ) (Petković et al., 2020).

The following raw materials were used to produce bread samples: T400 wheat flour (Danubius, Serbia; total water $15 \%$, total ash $<0.45 \%$, total proteins $10.3 \%$, total starch $68 \%$, total sugar $1.8 \%$, total fat $1.0 \%$, total fibers $4.0 \%$ ), palm fat (Oki, Malaysia), baking yeast (Saccharomyces cerevisiae, Alltech Fermin, Serbia), sucrose (Crvenka, Serbia) and distilled water, all obtained at the local market.

\subsection{Methods}

\subsubsection{Breadmaking process and raw materials used in bread formulation}

The bread dough formula was expressed on a flour basis (Petković et al., 2020). It consisted of flour (T400 wheat flour), CP (in the amount of 1, 2.5, 5 and 10\%), crystal sugar (sucrose, 1.50\%), salt (1.85\%), fresh yeast $(3.0 \%)$, palm fat $(1.85 \%)$ and distilled water, defined by optimum absorption, corresponding to 500 BU (Brabender Units, 58.0\%). Chokeberry powders were labeled with $\mathrm{CP}$ level and dehydration temperature. Control bread sample (C) was produced without $\mathrm{CP}$, and the other bread samples contained wheat flour supplemented with $1 \%, 2.5 \%, 5 \%$, and $10 \%$ CP, respectively. Bread samples with chokeberry powder were labeled with chokeberry level in the superscript and drying temperature in the subscript. Flour, CP, yeast, salt, and other ingredients were mixed in a Diosna-type mixer for 3 minutes. The dough was removed from the mixer, measured, shaped, and fermented in a maturograph fermentation chamber at $30^{\circ} \mathrm{C}$ for 90 minutes, with occasional re-mixing. After fermentation, the dough was split, shaped, and placed on a piece of canvas in a knitted basket for final fermentation (50 minutes of fermentation, $30^{\circ} \mathrm{C}$ and relative humidity of $75 \%$ ). Afterward, the bread was baked in a laboratory oven (MD/CO/S/B18, Mac-Pan, Thiene, Italy) for 20 minutes at $220-250^{\circ} \mathrm{C}$. The laboratory oven was saturated with water steam. After the baking process, bread was placed on a wooden grid to cool down, wrapped in aluminum foil and left for 24 hours at room temperature.

\subsubsection{Basic chemical analysis}

Basic chemical analyses were performed according to the official methods of AOAC (total starch TSt; AOAC 945.37 1945, AOAC 996.12005 ), protein (TP; AOAC 950.36 1950, AOAC 997.06 2005), total sugar (TS; AOAC 975.14 1975, AOAC 939.03 1939), and fat (TF; AOAC 922.06 1922, AOAC 934.01 1934). Fundamental chemical analyses of loss on drying (moisture) in fresh fruits, dried fruits and bread were determined according to the official methods of AOAC (AOAC 934.06 1934, AOAC 935.37 1935, and AOAC 935.36 1935 , respectively).

\subsubsection{Determination of mineral content}

The contents of zinc, copper, magnesium, calcium, and iron in bread and chokeberry samples were determined using an atomic absorption spectrophotometer, AOAC (AOAC 945.411945, AOAC 999.10 2005).

\subsubsection{Determination of fatty acids - GC-MS analysis}


The fat phase for fatty acid (FA) analysis was extracted by the Folch method to isolate total lipids. FA methyl esters were prepared from the extracted lipids by the transmethylation method using $14 \%$ wt. boron trifluoride/methanol solution (Karlović and Andrić, 1996). The obtained samples were analyzed by an Agilent 7890A gas chromatographer (Agilent Technologies, CA, USA) with a flame ionization detector (GC-FID), and an automatic liquid sampler, equipped with a fused silica capillary column (Supelco SP-2560 Capillary GC Column $100 \mathrm{~m} \times 0.25 \mathrm{~mm}, \mathrm{~d}=0,20 \mu \mathrm{m}$ ), and helium as a carrier gas (purity $=99,9997$ vol \%, flow rate $=1.5 \mathrm{~mL} \mathrm{~min}^{-1}$ and pressure $=1,092 \mathrm{bar}$ ). The samples were injected in volumes of $1 \mu \mathrm{L}$ with a split ratio of 30:1. The following temperature regime was applied: initial temperature $140^{\circ} \mathrm{C}$, initial temperature hold time $5 \mathrm{~min}$, heating rate $3^{\circ} \mathrm{C} \mathrm{min}^{-1}$, final temperature $240^{\circ} \mathrm{C}$ and final temperature hold time 10 min. Nitrogen was used as a makeup gas. FA peaks were identified by comparing their retention times with those of standards from "Supelco 37 component FA methyl ester mix" and data from an internal data library, based on previous experiments and FA methyl ester determination by GC-MS. The results were expressed as the mass of individual fatty acid group (g) in $100 \mathrm{~g}$ of fatty acids or relative mass contents.

\subsubsection{Methods of statistical analysis}

Response surface methodology (RSM) and analysis of variance (ANOVA) were used to estimate the main effect of the process variables (chokeberry addition and chokeberry drying temperature) on the nutritional quality parameters of bread with added chokeberry.

The independent variables were chokeberry addition $\left(\mathrm{X}_{1}\right)$ of $1,2.5,5$ and $10 \%$ and chokeberry drying temperature $\left(\mathrm{X}_{2}\right)$ of 50,60 , and $70^{\circ} \mathrm{C}$. The dependent variables were the chemical composition responses $\left(\mathrm{Y}_{1}-\mathrm{Y}_{3}\right)$, mineral composition responses $\left(\mathrm{Y}_{4}-\mathrm{Y}_{8}\right)$, and fat and fatty acids content (Y9-Y15). Models were fitted to the response surface generated by the experiment. The following second-order polynomial (SOP) model was fitted to the data:

$$
Y_{k}=B_{k 0}+\sum_{i=1}^{2} B_{k i} X_{i}+\sum_{i=1}^{2} B_{k i i} X_{i}^{2}+B_{k i j} X_{i} X_{j}, \mathrm{k}=1-15
$$

where $\beta_{\mathrm{kij}}$ are constant regression coefficients.

The Z-Score analysis uses min-max normalization of different bread quality responses, migrating them from their original unit system to a new dimensionless unit system, where further mathematical calculations are performed (Filipović et al. 2020, Jayalakshmi and Santhakumaran 2012). The maximum value of normalized Z-score presents the optimum value of all combined analyzed parameters, indicating the optimum total quality:

Chemical composition segment score:

$S_{1 i}=\frac{\sum_{k=1}^{2} \frac{\left(x_{k j}-x_{k \text { min }}\right)}{\left(x_{k \text { max }}-x_{k \text { min }}\right)}+\left(1-\frac{\left(x_{j}-x_{j \text { min }}\right)}{\left(x_{j} \text { max }-x_{j \text { min }}\right)}\right)}{3}$ where $\mathrm{xk}$ are: total proteins and sugars, and $\mathrm{x}_{\mathrm{j}}$ is: total starch;

Mineral composition segment score:

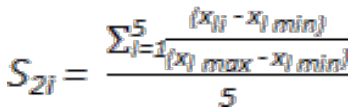

where $\mathrm{x}_{\mathrm{l}}$ are: $\mathrm{Zn}, \mathrm{Cu}, \mathrm{Mg}$, $\mathrm{Ca}$ and $\mathrm{Fe}$;

Fat and fatty acids content segment score:

$S_{3 j}=\frac{\sum_{m=1}^{4} 1-\frac{\left(x_{m i}-x_{m \text { min }}\right)}{\left(x_{m \text { max }}-x_{m \text { min }}\right)}+\sum_{n=1}^{3} \frac{\left(x_{n j}-x_{n \text { min }}\right)}{7}}{7}$

where $\mathrm{xm}$ are: total fat, and palmitic, stearic and saturated fatty acids, while xn are: oleic, linoleic and linolenic acids

Total nutritive score:

Score $_{\hat{\gamma}}=\frac{\sum_{0=1}^{3} s_{0}}{3}$

where $S_{o}$ are $S_{1}, S_{2}$ and $S_{3}$;

$\max \left[\right.$ Score $\left._{i}\right] \rightarrow$ optimum

Statistical analysis of experimental data was performed using StatSoft Statistica ver.12.0.

\section{Results and discussions}

\subsection{Basic chemical quality of chokeberry powders}

The nutritive value of chokeberries depends on many factors, e.g. variety, maturity, and environmental and climatic conditions (Kader and Barrett, 2004, Sidor et al., 2019, Sidor and Gramza-Michałowska, 2019). The chemical composition and mineral content of CP are presented in Tables 1 and 2. All values were presented as a percentage of dry weight of chokeberry fruits (DW).

The protein fraction of chokeberries was up to 0.7 g $100 \mathrm{~g}^{-1} \mathrm{FW}$ [Tanaka and Tanaka, 2001]. TP content was $4.21 \%$ to $4.58 \%$ DW (Table 1, 4.21-4.58 mg kg-1 DW). Proteins were located in seeds. TP content in seeds was 4-fold higher than that in seedless pulp (Gustinelli et al., 2018). CP TP content statistically significantly decreased with increasing drying temperature. The applied fertilization had a differential influence on the total sugar content $(20.92 \% \mathrm{FW})$ of chokeberries (Skupien and Oszmianski, 2007). CP was a rich source of sugars (Table 1, 24.39-24.57 mg 100 $\mathrm{mg}^{-1}$ DW). TS content might depend upon the morphological part, e.g. the sucrose present in seeds is an essential compound in plant growth. The drying temperature of chokeberry did not statistically significantly affect the TS content of C 
Table 1.

Chemical composition and mineral content of dried chokeberry fruits and bread samples with dried chokeberry

\begin{tabular}{|c|c|c|c|c|c|c|c|c|}
\hline $\begin{array}{l}\text { Sample } \\
\text { no. }\end{array}$ & TSt & $\begin{array}{c}\mathrm{TP} \\
(\% \mathrm{DW})\end{array}$ & TS & $\mathrm{Zn}$ & $\mathrm{Cu}$ & $\begin{array}{c}\mathrm{Mg} \\
\text { (mg kg-1 DW }\end{array}$ & $\mathrm{Ca}$ & $\mathrm{Fe}$ \\
\hline CP50 & $0.00 \pm 0.00$ & $4.58 \pm 0.03$ & $24.57 \pm 0.11$ & $8.68 \pm$ & $6.96 \pm 0.05$ & $735.42 \pm 10.82$ & $191.4 \pm 2.53$ & $36.09 \pm$ \\
\hline & $\mathrm{a}$ & $\mathrm{a}$ & $\mathrm{a}$ & $0.09 \mathrm{a}$ & $\mathrm{a}$ & $\mathrm{a}$ & $\mathrm{a}$ & $0.21 \mathrm{a}$ \\
\hline СР 60 & $0.00 \pm 0.00$ & $4.44 \pm 0.05$ & $24.42 \pm 0.26$ & $7.75 \pm$ & $8.89 \pm 0.06$ & $846.11 \pm 9.42$ & $227.6 \pm 2.18$ & $36.64 \pm$ \\
\hline & $\mathrm{a}$ & b & $\mathrm{a}$ & $0.12 \mathrm{~b}$ & b & $\mathrm{b}$ & $\mathrm{b}$ & $0.46 \mathrm{~b}$ \\
\hline CP70 & $\begin{array}{c}0.00 \pm 0.00 \\
\mathrm{a}\end{array}$ & $\begin{array}{c}4.21 \pm 0.05 \\
\text { c }\end{array}$ & $\begin{array}{c}24.39 \pm 0.10 \\
a\end{array}$ & $\begin{array}{l}8.00 \pm \\
0.07 \mathrm{c}\end{array}$ & $\begin{array}{c}4.81 \pm 0.04 \\
c\end{array}$ & $\begin{array}{c}867.34 \pm 2.63 \\
\text { c }\end{array}$ & $\begin{array}{c}218.8 \pm 1.51 \\
c\end{array}$ & $\begin{array}{c}29.77 \pm \\
0.14 \mathrm{c}\end{array}$ \\
\hline$C_{50}^{1}$ & $\begin{array}{c}79.32 \pm 0.88 \\
\text { de }\end{array}$ & $\begin{array}{c}12.11 \pm 0.11 \\
\mathrm{~d}\end{array}$ & $\begin{array}{c}2.30 \pm 0.03 \\
b\end{array}$ & $\begin{array}{l}9.92 \pm \\
0.04 \mathrm{a}\end{array}$ & $\begin{array}{c}2.49 \pm 0.03 \\
\mathrm{ab}\end{array}$ & $\begin{array}{c}210.37 \pm 4.03 \\
\mathrm{ab}\end{array}$ & $\begin{array}{c}201.99 \pm \\
2.69 \mathrm{a}\end{array}$ & $\begin{array}{c}37.02 \pm \\
0.35 \mathrm{a}\end{array}$ \\
\hline$C_{50}^{2.5}$ & $\begin{array}{c}76.46 \pm 0.58 \\
c\end{array}$ & $\begin{array}{c}12.00 \pm 0.18 \\
\mathrm{~d}\end{array}$ & $\begin{array}{c}2.63 \pm 0.05 \\
\mathrm{c}\end{array}$ & $\begin{array}{l}9.90 \pm \\
0.11 \mathrm{a}\end{array}$ & $\begin{array}{c}2.56 \pm 0.03 \\
b c\end{array}$ & $\begin{array}{c}217.25 \pm 1.97 \\
\text { bc }\end{array}$ & $\begin{array}{c}201.19 \pm \\
1.32 \mathrm{a}\end{array}$ & $\begin{array}{c}37.00 \pm \\
0.37 \mathrm{a}\end{array}$ \\
\hline$C_{50}^{5}$ & $\begin{array}{c}75.14 \pm 1.07 \\
\text { bc }\end{array}$ & $\begin{array}{c}11.87 \pm 0.14 \\
\mathrm{~d}\end{array}$ & $\begin{array}{c}3.21 \pm 0.03 \\
\mathrm{e}\end{array}$ & $\begin{array}{l}9.87 \pm \\
0.12 \mathrm{a}\end{array}$ & $\begin{array}{c}2.67 \pm 0.03 \\
\mathrm{~d}\end{array}$ & $\begin{array}{c}231.31 \pm 4.82 \\
d\end{array}$ & $\begin{array}{c}200.99 \pm \\
2.31 \mathrm{a}\end{array}$ & $\begin{array}{c}36.98 \pm \\
0.72 \mathrm{a}\end{array}$ \\
\hline$C_{50}^{10}$ & $\begin{array}{c}70.33 \pm 0.36 \\
a\end{array}$ & $\begin{array}{c}11.12 \pm 0.05 \\
\mathrm{a}\end{array}$ & $\begin{array}{c}4.32 \pm 0.06 \\
\mathrm{f}\end{array}$ & $\begin{array}{l}9.81 \pm \\
0.06 \mathrm{a}\end{array}$ & $\begin{array}{c}2.90 \pm 0.03 \\
\mathrm{f}\end{array}$ & $\begin{array}{c}257.42 \pm 4.99 \\
\mathrm{e}\end{array}$ & $\begin{array}{c}200.43 \pm \\
1.78 \mathrm{a}\end{array}$ & $\begin{array}{c}36.90 \pm \\
0.55 \mathrm{a}\end{array}$ \\
\hline$C_{60}^{1}$ & $\begin{array}{c}79.51 \pm 1.14 \\
\text { de }\end{array}$ & $\begin{array}{c}12.10 \pm 0.22 \\
\mathrm{~d}\end{array}$ & $\begin{array}{c}2.90 \pm 0.03 \\
\mathrm{~d}\end{array}$ & $\begin{array}{l}9.92 \pm \\
0.11 \mathrm{a}\end{array}$ & $\begin{array}{c}2.51 \pm 0.03 \\
a b\end{array}$ & $\begin{array}{c}210.19 \pm 1.98 \\
a b\end{array}$ & $\begin{array}{c}201.70 \pm \\
1.04 \mathrm{a}\end{array}$ & $\begin{array}{c}37.00 \pm \\
0.65 \mathrm{a}\end{array}$ \\
\hline$C_{60}^{2.5}$ & $\begin{array}{c}76.41 \pm 1.37 \\
\text { c }\end{array}$ & $\begin{array}{c}11.95 \pm 0.13 \\
\mathrm{~d}\end{array}$ & $\begin{array}{c}2.63 \pm 0.02 \\
\mathrm{c}\end{array}$ & $\begin{array}{l}9.88 \pm \\
0.17 \mathrm{a}\end{array}$ & $\begin{array}{l}2.61 \pm 0.01 \\
\mathrm{~cd}\end{array}$ & $\begin{array}{c}220.77 \pm 1.50 \\
\text { c }\end{array}$ & $\begin{array}{c}202.45 \pm \\
1.62 \mathrm{a}\end{array}$ & $\begin{array}{c}37.01 \pm \\
0.55 \mathrm{a}\end{array}$ \\
\hline$C_{60}^{5}$ & $\begin{array}{c}75.85 \pm 0.92 \\
\text { c }\end{array}$ & $\begin{array}{l}11.79 \pm 0.11 \\
\mathrm{~cd}\end{array}$ & $\begin{array}{c}3.19 \pm 0.04 \\
\mathrm{e}\end{array}$ & $\begin{array}{l}9.80 \pm \\
0.11 \mathrm{a}\end{array}$ & $\begin{array}{c}2.76 \pm 0.02 \\
\mathrm{e}\end{array}$ & $\begin{array}{c}236.81 \pm 4.75 \\
d\end{array}$ & $\begin{array}{c}202.99 \pm \\
2.89 \mathrm{a}\end{array}$ & $\begin{array}{c}37.02 \pm \\
0.49 \mathrm{a}\end{array}$ \\
\hline $\mathrm{C}_{60}^{10}$ & $\begin{array}{c}71.44 \pm 0.14 \\
\mathrm{a}\end{array}$ & $\begin{array}{c}11.41 \pm 0.20 \\
\text { a-c }\end{array}$ & $\begin{array}{c}4.31 \pm 0.06 \\
\mathrm{f}\end{array}$ & $\begin{array}{l}9.71 \pm \\
0.21 \mathrm{a}\end{array}$ & $\begin{array}{c}3.09 \pm 0.01 \\
\mathrm{~g}\end{array}$ & $\begin{array}{c}267.99 \pm 4.59 \\
f\end{array}$ & $\begin{array}{c}204.06 \pm \\
1.26 \mathrm{a}\end{array}$ & $\begin{array}{c}36.99 \pm \\
0.33 \mathrm{a}\end{array}$ \\
\hline$C_{70}^{1}$ & $\begin{array}{c}80.29 \pm 1.13 \\
\mathrm{e}\end{array}$ & $\begin{array}{c}12.10 \pm 0.07 \\
\mathrm{~d}\end{array}$ & $\begin{array}{c}2.83 \pm 0.04 \\
\mathrm{~d}\end{array}$ & $\begin{array}{l}9.92 \pm \\
0.11 \mathrm{a}\end{array}$ & $\begin{array}{c}2.46 \pm 0.02 \\
a\end{array}$ & $\begin{array}{c}211.36 \pm 1.69 \\
\text { a-c }\end{array}$ & $\begin{array}{c}201.61 \pm \\
1.93 \mathrm{a}\end{array}$ & $\begin{array}{c}36.96 \pm \\
0.39 \mathrm{a}\end{array}$ \\
\hline$C_{70}^{2.5}$ & $\begin{array}{c}77.46 \pm 0.81 \\
\text { cd }\end{array}$ & $\begin{array}{c}11.90 \pm 0.09 \\
\mathrm{~d}\end{array}$ & $\begin{array}{c}2.63 \pm 0.02 \\
c\end{array}$ & $\begin{array}{l}9.90 \pm \\
0.11 \mathrm{a}\end{array}$ & $\begin{array}{c}2.51 \pm 0.02 \\
\mathrm{ab}\end{array}$ & $\begin{array}{c}220.49 \pm 1.21 \\
c\end{array}$ & $\begin{array}{c}202.44 \pm \\
2.27 \mathrm{a}\end{array}$ & $\begin{array}{c}36.99 \pm \\
0.34 \mathrm{a}\end{array}$ \\
\hline$C_{70}^{5}$ & $\begin{array}{c}75.67 \pm 1.05 \\
c\end{array}$ & $\begin{array}{c}11.74 \pm 0.16 \\
\text { b-d }\end{array}$ & $\begin{array}{c}3.21 \pm 0.04 \\
\mathrm{e}\end{array}$ & $\begin{array}{l}9.85 \pm \\
0.07 \mathrm{a}\end{array}$ & $\begin{array}{c}2.55 \pm 0.03 \\
\text { bc }\end{array}$ & $\begin{array}{c}267.19 \pm 2.29 \\
f\end{array}$ & $\begin{array}{c}202.87 \pm \\
1.84 \mathrm{a}\end{array}$ & $\begin{array}{c}36.66 \pm \\
0.72 \mathrm{a}\end{array}$ \\
\hline$C_{70}^{10}$ & $\begin{array}{c}72.92 \pm 0.36 \\
\text { ab }\end{array}$ & $\begin{array}{c}11.30 \pm 0.09 \\
\mathrm{ab}\end{array}$ & $\begin{array}{c}4.29 \pm 0.04 \\
\mathrm{f}\end{array}$ & $\begin{array}{l}9.73 \pm \\
0.11 \mathrm{a}\end{array}$ & $\begin{array}{c}2.68 \pm 0.03 \\
d\end{array}$ & $\begin{array}{c}271.06 \pm 2.56 \\
f\end{array}$ & $\begin{array}{c}203.17 \pm \\
1.19 \mathrm{a}\end{array}$ & $\begin{array}{c}36.30 \pm \\
0.15 \mathrm{a}\end{array}$ \\
\hline $\mathrm{C}$ & $\begin{array}{c}80.87 \pm 1.03 \\
\text { e }\end{array}$ & $\begin{array}{c}12.18 \pm 0.24 \\
\mathrm{~d}\end{array}$ & $\begin{array}{c}2.06 \pm 0.02 \\
\mathrm{a}\end{array}$ & $\begin{array}{l}9.93 \pm \\
0.14 \mathrm{a}\end{array}$ & $\begin{array}{c}2.44 \pm 0.01 \\
a\end{array}$ & $\begin{array}{c}203.72 \pm 1.43 \\
a\end{array}$ & $\begin{array}{c}201.44 \pm \\
2.01 \mathrm{a}\end{array}$ & $\begin{array}{c}37.03 \pm \\
0.29 \mathrm{a}\end{array}$ \\
\hline
\end{tabular}

$*$ Mean value \pm standard deviation $(n=3)$

$\mathrm{a}-\mathrm{h}=$ Different superscript letters in the column table indicate statistically significant differences between values, at the significance level of $P<0.05$ (based on Tukey's HSD test).

The content of essential elements was higher due to a higher plant matter per water and due to extraction conditions (processing) (Šavikin et al., 2014; Juranović-Cindric et al., 2017). The analysis of the mineral content, Table 1, showed that $\mathrm{CP}$ was a good source of magnesium (735.42-867.34 $\left.\mathrm{mg} \mathrm{kg}^{-1} \mathrm{DW}\right)$, calcium (191.4-218.8 mg kg-1 DW), and iron (29.77$36.66 \mathrm{mg} \mathrm{kg}^{-1} \mathrm{DW}$ ). In chokeberries, magnesium was located in the seed at 10 -fold higher levels than in the seedless pulp and could be transferred into the juice (Sójka et al., 2013). Regardless of magnesium, calcium was located in the skin and was not transferred into the juice (AIJN 2001). Iron was located in the seedless pulp, and the concentrations of zinc (3-6-fold higher) and copper (2-fold higher) were dominant in the seed (Sójka et al., 2013). Increasing drying temperature statistically significantly decreased the content of minerals in CP.

The total fat content of chokeberries was $0.14 \mathrm{~g}$ $100 \mathrm{~g}^{-1} \mathrm{FW}$ (Tanaka and Tanaka, 2001). As indicated by the research results in Table 2, TF obtained from CP was a rich source of saturated palmitic acid (C16:0, $12.8-14.46 \%$ of $\mathrm{TF}$ content) and unsaturated acids, such as oleic acid (C18:1, 8.77-10.82\% of total fat content) and linoleic acid (C18:2, 63.73-66.21\% of TF content). The chokeberry oil was rich in phospholipids, sterols, tocopherols, and the dominating unsaturated acids C18:2 and C18:1 (Zlatanov, 1999). The fat components were generally located in the seeds.
Linoleic and oleic acids are the most potent fatty acids for lowering triacylglycerols (LDL)-cholesterol and (HDL)-cholesterol levels (Dubois et al., 2007). Increasing drying temperature statistically significantly decreased the contents of fat and fatty acids in CP.

\subsection{Basic chemical quality of bread samples with dried chokeberry}

Fortification is a standard method to improve the functional properties of bread. Adding ingredients could also influence other parameters, such as nutritional and sensory properties (Dziki et al., 2014; Ezhilarasi et al., 2014; Kobus-Cisowska et al., 2020).

Bread and biscuits fortified with Aronia (chokeberry) had a high content of protein (11.92$12.95 \%$ ) and minerals (ash, 1.51-2.03\%), and a low sugar content (4.33-5.79\%) (Catană et al., 2018). Type 400 wheat flour was a source of starch $(68 \% 80 \%$ DW). As starch existed in granular shape, the swelling of starch granules influenced dough structure and rheology. Waxy starch, rich in amylopectin, displayed higher swelling ability in comparison to amylose starch (Šárka and Dvořáček, 2017). Bread samples were rich sources of carbohydrates, such as starch (Table 1, $80.87 \pm 1.03 \%$ DW). As the level of CP increased, TSt of bread statistically significantly decreased, with no statistically significant effect of dehydration temperature on TSt results. Bread samples with $10 \%$ of 
CP had a TSt $70.39-72.92 \%$ DW. The structure and texture of wheat bakery products depended mostly on the quality of starch as the major constituent of flour in bread formulations. The type and origin of starch had an important effect on the microstructure and rheological properties of dough, water retention, and quality of the final product, such as bread (Zhang et al., 2017). During dough preparation and bread baking, structure formation was related to fractional starch gelatinization and interactions between starch polymers and other substances present. Bread samples with a higher content of CP had a less developed structure.

Adding 1 to $5 \%$ of chokeberry powder improves gluten quality by $5.4 \%$ (Koshak and Pokrashinskaya, 2020 ). Wheat proteins are gluten proteins (80 to 85\% of total wheat protein) and nongluten proteins (15 to $20 \%$ of total wheat protein). Gluten proteins are vital from a technological point of view because they are responsible for the viscoelastic properties of wheat flour dough after hydration. Monomeric gluten proteins (gliadins) confer viscosity to such dough; polymeric gluten proteins (glutenin) are responsible for dough elasticity (Veraverbeke and Delcour, 2002). TP content in T400 wheat flour was $10.3 \%(12.1 \% \mathrm{DW})$ and in CP $4.21-4.58 \%$ DW (Table 1). As the amount of CP increased, the TP of bread statistically significantly decreased, with no statistically significant effect of dehydration temperature on TP results. The $\mathrm{pH}$ values of CP and bread samples are low (Petković et al., 2020). Under low acidity conditions, gluten does not swell, but is peptized to a colloidal solution. CP has components with an oxidative potential, which helped to form disulfide bonds between the quaternary and tertiary structures of protein molecules, thereby strengthening the gluten network (Koshak and Pokrashinskaya, 2020). Wheat flour, as a bread ingredient, had higher TP values than CP. Bread samples with $10 \%$ of CP had TP levels between 11.12 and $11.41 \%$ DW. Wheat flour breadmaking performance was linearly related to gluten protein content. Thus, the high quality and quantity of gluten proteins were important (Shewry, 2010).

Due to the low content of sugars (especially sorbitol), bakery products fortified with Aronia could be included in the diet of people with type 2 diabetes and obesity (Catană et al., 2018; Denev et al., 2018). Total sugars in wheat flour were very low. Glucose was the most abundant reducing sugar $(0.1 \pm 0.0 \% \mathrm{DW})$, followed by maltose $(0.2 \pm 0.0 \%$ DW $)$, while sucrose $(0.4 \pm 0.0 \% \mathrm{DW})$ as a non-reducing sugar was highest in bread wheat wholemeal (Hidalgo and Brandolini, 2011; Hidalgo et al., 2019). Bread without CP (C) had the lowest TS values (Table 1, 2.06 $\pm 0.02 \%$ DW). Adding CP as a wheat flour substitute led to an increase in TS content due to high TS values in CP (24.39-24.57\% DW). As the level of CP increased, the TS of bread statistically significantly increased, with no statistically significant effect of dehydration temperature on TS results. Bread samples with $10 \%$ of CP had the highest TS content (Table 1, 4.29-4.32\% DW). The TS values of bread samples were higher for the content of sucrose $(1.5 \%)$, which was added to the dough formula.

The addition of CP affected the mineral content of developed bread compared to the control (Table 1). Zn, $\mathrm{Ca}$, and Fe contents were not statistically significantly affected by the quantity of chokeberry addition and chokeberry drying temperature. There was also no statistically significant difference between $\mathrm{C}$ and bread with CP. However, the levels of $\mathrm{Cu}\left(2.46-3.09 \mathrm{mg} \mathrm{kg}^{-1}\right.$ DW) and Mg (210.19-271.06 $\mathrm{mg} \mathrm{kg}^{-1} \mathrm{DW}$ ) in bread statistically significantly increased with increasing amount of chokeberry. Chokeberry drying temperature also statistically significantly affected the $\mathrm{Cu}$ and $\mathrm{Mg}$ contents of bread.

High lipid and fiber contents in bread dough make amylopectin recrystallization more difficult and reduce retrogradation (Mondragón et al., 2006). The total fat in wheat flour was deficient. TF in T400 wheat flour was about $1.0 \%$, which was generally the average $\mathrm{TF}$ content in many scientific papers, such as Mau et al. (2020). Enrichment of bakery products (such as muffins) with black chokeberry polyphenol extract significantly improved their antioxidative potential and protected the lipid fraction concerning the generation of toxic secondary lipid oxidation products (Rutkowska et al., 2020). CP was low in fats (1.64-1.68\% DW, Table 2 ), especially saturated fats. Palm fat used in bread formulations was the source of fat, especially saturated fatty acids, in bread samples. Palm fat was a rich source of saturated (49.5-82.2\%) and monounsaturated (15.4-40.00\%) fatty acids. The dominant fatty acids in crude palm oil were palmitic acid (C16:0, 43.7\%) and oleic acid (C18:1, 39.9\%), whereas lauric acid (C12:0, 48.0\%), myristic acid (C14:0, 16.0\%) and oleic acid (C18:1, 15.4\%) were dominant in palm kernel oil (Elson and Alfin-Slater 1992). Vegetable fat could help the absorption of fat-soluble minerals and vitamins. The statistically significant increase in $\mathrm{TF}$ in bread samples was related to increased amounts of $\mathrm{CP}$ in bread formulation, especially those above $2.5 \%$. The main reason for the increase in the TF content of bread was unsaturated fatty acids, such as linoleic acid (C18:2), as the predominant fatty acid in CP (Table 2, 63.72-66.21 \% d.m.). The addition of CP statistically significantly increased the linoleic and linolenic acid content of bread samples. Bread samples were not a rich source of fat, and the dominant fatty acids were palmitic (C16:0, 31.09-32.95\% DW), oleic (C18:1, 27.42-29.27\% DW), and linoleic (C12:0, 32.38-35.49\% DW) fatty acids. The larger the accumulation of proteinand starch-bound lipids during fermentation and baking, the higher the physico-chemical and sensory profiles, and the slower the starch hydrolysis, firming, and retrogradation kinetics of composite bread samples (Collar and Conte 2016). Lipid oxidation in fresh bread was significantly reduced by fortifying bread with freeze-dried vegetables (Ranawana et al., 2016). pH affected lipid oxidation, which was greater under neutral conditions than under acidic conditions (Richards and Hultin, 2000). 
Table 2.

Fat and fatty acid content of dried chokeberry fruits and bread samples with dried chokeberry

\begin{tabular}{|c|c|c|c|c|c|c|c|}
\hline $\begin{array}{c}\text { Sample } \\
\text { no. }\end{array}$ & $\begin{array}{c}\mathrm{TF} \\
(\% \mathrm{DW})\end{array}$ & $\begin{array}{l}\text { Palmitic acid } \\
(\mathrm{C} 16: 0) \text { (\% of } \\
\text { TF) }\end{array}$ & $\begin{array}{c}\text { Stearic acid } \\
\text { (C18:0) (\% of } \\
\text { TF) }\end{array}$ & $\begin{array}{c}\text { Oleic acid } \\
(\mathrm{C} 18: 1)(\% \text { of } \\
\text { TF) }\end{array}$ & $\begin{array}{c}\text { Linoleic acid } \\
\text { (C18:2) (\% of } \\
\text { TF) }\end{array}$ & $\begin{array}{c}\text { Linolenic acid } \\
(\mathrm{C} 18: 3 n-3) \\
(\% \text { of } \mathrm{TF})\end{array}$ & $\begin{array}{c}\mathrm{SFA}^{* *} \\
\text { (mg } 100 \mathrm{~g}- \\
1 \mathrm{DW})\end{array}$ \\
\hline CP50 & $\begin{array}{l}* 1.65 \pm \\
0.01 \mathrm{a}\end{array}$ & $12.84 \pm 0.20 \mathrm{a}$ & $2.90 \pm 0.03 \mathrm{a}$ & $10.81 \pm 0.08 \mathrm{a}$ & $66.21 \pm 0.30 a$ & $7.24 \pm 0.05 \mathrm{a}$ & $\begin{array}{c}\text { Not } \\
\text { detected }\end{array}$ \\
\hline CP60 & $\begin{array}{l}1.64 \pm \\
0.02 \mathrm{a}\end{array}$ & $14.46 \pm 0.25 b$ & $3.18 \pm 0.02 b$ & $9.00 \pm 0.14 b$ & $63.72 \pm 0.59 \mathrm{~b}$ & $9.63 \pm 0.07 c$ & $\begin{array}{c}\text { Not } \\
\text { detected }\end{array}$ \\
\hline CP70 & $\begin{array}{l}1.68 \pm \\
0.02 b\end{array}$ & $13.64 \pm 0.18 c$ & $2.86 \pm 0.02 c$ & $8.77 \pm 0.08 c$ & $65.35 \pm 0.64 c$ & $9.38 \pm 0.11 b$ & $\begin{array}{c}\text { Not } \\
\text { detected }\end{array}$ \\
\hline $\mathrm{C}_{50}^{1}$ & $\begin{array}{l}0.87 \pm \\
0.01 \mathrm{a}\end{array}$ & $32.91 \pm 0.51 \mathrm{c}$ & $3.65 \pm 0.04 \mathrm{a}$ & $29.27 \pm 0.04 \mathrm{~cd}$ & $32.39 \pm 0.57 \mathrm{a}$ & $1.79 \pm 0.01 \mathrm{ab}$ & $\begin{array}{l}36.01 \pm \\
0.32 \mathrm{c}-\mathrm{f}\end{array}$ \\
\hline $\mathrm{C}_{50}^{2.5}$ & $\begin{array}{c}0.90 \pm \\
0.01 \mathrm{bc}\end{array}$ & $32.66 \pm 0.37 c$ & $3.64 \pm 0.05 \mathrm{a}$ & $28.99 \pm 0.05 \mathrm{~cd}$ & $32.90 \pm 0.29 \mathrm{ab}$ & $1.87 \pm 0.02 \mathrm{~cd}$ & $\begin{array}{l}35.68 \pm \\
0.43 \text { c-e }\end{array}$ \\
\hline $\mathrm{C}_{50}^{5}$ & $\begin{array}{c}0.92 \pm \\
0.02 \mathrm{~cd}\end{array}$ & $32.12 \pm 0.51 \mathrm{a}-\mathrm{c}$ & $3.63 \pm 0.05 a$ & $28.52 \pm 0.05 b-d$ & $33.78 \pm 0.36 b$ & $2.01 \pm 0.02 \mathrm{e}$ & $\begin{array}{c}35.14 \pm \\
0.35 b-d\end{array}$ \\
\hline $\mathrm{C}_{50}^{10}$ & $\begin{array}{l}0.97 \pm \\
0.01 \mathrm{e}\end{array}$ & $31.09 \pm 0.21 \mathrm{a}$ & $3.60 \pm 0.06 \mathrm{a}$ & $27.61 \pm 0.06 \mathrm{ab}$ & $35.49 \pm 0.49 c$ & $2.28 \pm 0.01 \mathrm{~g}$ & $\begin{array}{c}34.35 \pm \\
0.34 \mathrm{~b}\end{array}$ \\
\hline $\mathrm{C}_{60}^{1}$ & $\begin{array}{l}0.87 \pm \\
0.01 \mathrm{a}\end{array}$ & $32.95 \pm 0.29 c$ & $3.64 \pm 0.04 \mathrm{a}$ & $29.27 \pm 0.04 \mathrm{~cd}$ & $32.38 \pm 0.31 \mathrm{a}$ & $1.81 \pm 0.02 \mathrm{bc}$ & $\begin{array}{l}36.09 \pm \\
0.42 \mathrm{~d}-\mathrm{f}\end{array}$ \\
\hline $\mathrm{C}_{60}^{2.5}$ & $\begin{array}{c}0.90 \pm \\
0.02 \mathrm{bc}\end{array}$ & $32.77 \pm 0.28 c$ & $3.63 \pm 0.03 a$ & $28.96 \pm 0.02 \mathrm{~cd}$ & $32.89 \pm 0.06 \mathrm{ab}$ & $1.93 \pm 0.03 \mathrm{~d}$ & $\begin{array}{c}36.81 \pm \\
0.37 \mathrm{f}\end{array}$ \\
\hline $\mathrm{C}_{60}^{5}$ & $\begin{array}{c}0.92 \pm \\
0.01 \mathrm{~cd}\end{array}$ & $31.18 \pm 0.15 \mathrm{ab}$ & $3.61 \pm 0.04 \mathrm{a}$ & $28.49 \pm 0.04 b c$ & $33.72 \pm 0.16 b$ & $2.13 \pm 0.03 \mathrm{f}$ & $\begin{array}{l}35.59 \pm \\
0.03 \text { c-e }\end{array}$ \\
\hline $\mathrm{C} \frac{10}{60}$ & $\begin{array}{l}0.96 \pm \\
0.01 \mathrm{e}\end{array}$ & $31.29 \pm 0.43 \mathrm{ab}$ & $3.58 \pm 0.05 a$ & $27.42 \pm 0.05 a$ & $35.38 \pm 0.46 c$ & $2.52 \pm 0.02 \mathrm{~h}$ & $\begin{array}{c}32.79 \pm \\
0.23 \mathrm{a}\end{array}$ \\
\hline $\mathrm{C}_{70}^{1}$ & $\begin{array}{l}0.87 \pm \\
0.01 \mathrm{a}\end{array}$ & $32.92 \pm 0.36 \mathrm{c}$ & $3.64 \pm 0.08 \mathrm{a}$ & $29.25 \pm 0.08 \mathrm{~cd}$ & $32.39 \pm 0.21 \mathrm{a}$ & $1.81 \pm 0.02 b$ & $\begin{array}{c}36.22 \pm \\
0.42 \text { ef }\end{array}$ \\
\hline $\mathrm{C}_{70}^{2.5}$ & $\begin{array}{c}0.90 \pm \\
0.01 \mathrm{bc}\end{array}$ & $32.65 \pm 0.25 c$ & $3.63 \pm 0.04 \mathrm{a}$ & $28.98 \pm 0.04 \mathrm{~cd}$ & $32.87 \pm 0.54 \mathrm{ab}$ & $1.92 \pm 0.03 \mathrm{~d}$ & $\begin{array}{l}34.97 \pm \\
0.30 \mathrm{bc}\end{array}$ \\
\hline $\mathrm{C}_{70}^{5}$ & $\begin{array}{l}0.93 \pm \\
0.01 \mathrm{~d}\end{array}$ & $32.19 \pm 0.02 b c$ & $3.61 \pm 0.01 \mathrm{a}$ & $28.43 \pm 0.01 b c$ & $33.64 \pm 0.17 b$ & $2.11 \pm 0.02 \mathrm{f}$ & $\begin{array}{c}33.09 \pm \\
0.33 \mathrm{a}\end{array}$ \\
\hline $\mathrm{C}_{70}^{10}$ & $\begin{array}{l}0.97 \pm \\
0.01 \mathrm{e}\end{array}$ & $31.20 \pm 0.33 \mathrm{ab}$ & $3.57 \pm 0.05 \mathrm{a}$ & $27.39 \pm 0.05 a$ & $35.22 \pm 0.33 c$ & $2.50 \pm 0.02 \mathrm{~h}$ & $\begin{array}{c}32.49 \pm \\
0.39 \mathrm{a}\end{array}$ \\
\hline $\mathrm{C}$ & $\begin{array}{c}0.88 \pm \\
0.02 \mathrm{ab}\end{array}$ & $33.11 \pm 0.57 \mathrm{c}$ & $3.65 \pm 0.04 \mathrm{a}$ & $29.46 \pm 0.03 \mathrm{~d}$ & $32.05 \pm 0.24 \mathrm{a}$ & $1.73 \pm 0.03 \mathrm{a}$ & $\begin{array}{c}36.75 \pm \\
0.41 \mathrm{f}\end{array}$ \\
\hline
\end{tabular}

\subsection{Statistical analysis}

Tables S1 to S3 present the results of the ANOVA analysis of the response surface models developed based on the experimental data on the chemical, mineral and fat and fatty acids contents of bread supplemented with chokeberry. The statistical significance of the models and residual variances are noted, and the values of the coefficient of determination $\left(\mathrm{R}^{2}\right)$ are shown in these tables.

In table S1, ANOVA results of the chemical content of bread with CP are shown. Only the linear terms of chokeberry addition for all tested responses (TP, TS, and TSt) were statistically significant. Residual variances were statistically insignificant in all cases of tested responses. High values of R2 that ranged from 0.96 to 0.97 indicated the excellent fit of developed models to the experimental data.

Table S2 shows ANOVA results of the mineral content of bread with CP. The linear terms of chokeberry addition and chokeberry drying temperature were statistically significant in all mineral content responses, except in the case of the linear term of chokeberry drying temperature for $\mathrm{Mg}$ and linear term of chokeberry addition for Ca. Quadratic term of chokeberry drying temperature was statistically significant in cases of $\mathrm{Zn}, \mathrm{Cu}, \mathrm{Ca}$, and Fe. Cross product term was statistically significant in cases of $\mathrm{Zn}$ and $\mathrm{Fe}$. Statistically insignificant residual variances and high values of $\mathrm{R}^{2}$ (ranged from 0.80 to 0.97 ) for all five models of bread with CP for mineral content indicate an excellent fit of developed models to the experimental data.

Table S3 shows the results of fat and fatty acid content of bread with CP. The linear term of chokeberry addition statistically significantly contributed to all fat and fatty acid content responses. Chokeberry addition quadratic term was statistically significant only in the case of fat content response. Chokeberry drying linear temperature term was statistically significant in stearic, oleic, linoleic, linolenic, and saturated fatty acid responses. Chokeberry drying quadratic temperature term was statistically significant in cases of stearic and linolenic acids. Cross product was statistically significant in cases of stearic, oleic, linoleic, and linolenic acids. Statistically insignificant residual variances and high values of $\mathrm{R}^{2}$ (ranging from 0.87 to 0.99 ) for all seven models of fat and fatty acid content of bread with CP indicate an excellent fit of developed models to the experimental data.

Regression coefficients of fifteen SOP models of chemical, mineral, and fat and fatty acid contents of bread with CP are shown in Tables S4 and S5. The statistical significance of individual coefficients is noted in these tables. Data from these tables can be used to complete SOP quadratic equations of bread with added chokeberry and predict and optimize bread with added chokeberry quality.

Table 3 shows the Z-Score analysis results indicating segment and total nutritive quality of tested bread samples. The highest values of all details and 
total scores were obtained for the same model $\left(\mathrm{C}_{60}^{10}\right)$. This result indicates that the bread sample with $10 \%$ of $\mathrm{CP}$ dried at a temperature of $60^{\circ} \mathrm{C}$ provided the best results for overall chemical composition, mineral composition, fat and fatty acid compositions, together with optimal total nutritive quality, expressed as maximal score value.

Table 3.

Score values of bread with added chokeberry quality parameters

\begin{tabular}{ccccc}
\hline Sample no. & $\mathrm{S}_{1}$ & $\mathrm{~S}_{2}$ & $\mathrm{~S}_{3}$ & Score \\
\hline $\mathbf{C}_{50}^{1}$ & 0.66 & 0.51 & 0.34 & 0.50 \\
$\mathbf{C}_{50}^{2.5}$ & 0.50 & 0.48 & 0.36 & 0.45 \\
$\mathbf{C}_{50}^{5}$ & 0.59 & 0.52 & 0.43 & 0.51 \\
$\mathbf{C}_{50}^{10}$ & 0.67 & 0.56 & 0.57 & 0.60 \\
\hline $\mathbf{C}_{60}^{1}$ & 0.48 & 0.49 & 0.35 & 0.44 \\
$\mathbf{C}_{60}^{2.5}$ & 0.49 & 0.56 & 0.34 & 0.46 \\
$\mathbf{C}_{60}^{5}$ & 0.54 & 0.62 & 0.54 & 0.56 \\
$\mathbf{C}_{60}^{10}$ & 0.72 & 0.78 & 0.68 & 0.73 \\
\hline $\mathbf{C}_{70}^{1}$ & 0.44 & 0.47 & 0.35 & 0.42 \\
$\mathbf{C}_{70}^{2.5}$ & 0.44 & 0.54 & 0.41 & 0.46 \\
$\mathbf{C}_{70}^{5}$ & 0.53 & 0.58 & 0.52 & 0.54 \\
$\mathbf{C}_{70}^{10}$ & 0.64 & 0.44 & 0.69 & 0.59 \\
\hline $\mathrm{C}$ & 0.33 & 0.46 & 0.27 & 0.35
\end{tabular}

\section{Conclusion}

At levels of $1,2.5,5$, and $10 \%$, chokeberry powder (CP) increases the attractiveness of bread in terms of its functionality. A new formulation of bread with $\mathrm{CP}$ was developed. CP could provide bioactive components, such as minerals (especially $\mathrm{Mg}$ and $\mathrm{Ca}$ ) and unsaturated fatty acids (especially linoleic acid), which are increasingly demanded due to their beneficial health-promoting effects.

Bread samples with CP were characterized by decreased starch and protein contents and increased sugar, $\mathrm{Mg}$, and $\mathrm{Ca}$ contents. The content of fat, especially favorable unsaturated fatty acids, in bread samples increased with increasing level of CP.

The developed mathematical models of bread fortified with CP showed a good correlation between calculated and measured values, providing a good basis for further product optimization. Z-score analysis indicated optimal segment and total nutritive quality of bread sample fortified with $10 \%$ of CP dried at a temperature of $60^{\circ} \mathrm{C}$.

\section{Acknowledgments}

The authors would like to acknowledge the financial support of the Ministry of Education, Science and Technological Development of the Republic of Serbia (Grant numbers: 451-03-68/2020-14/200134 and 451-03-68/2020-14/ 200222).

\section{Declaration of competing interest}

The authors declare no conflict of interest.

\section{References}

AIJN (2001). Code of Practice for the Evaluation of Fruit and Vegetable Juice. KUPSiNB, Warszawa.

AOAC 922.06 (1922), Fat in Flour. Acid hydrolysis method.

AOAC 934.01 (1934). Loss on drying (Moisture) at $95-100^{\circ} \mathrm{C}$. AOAC 934.06 (1996). Loss on Drying (Moisture) in Dried Fruit.

AOAC 935.36 (1935). Solids (Total) in Bread.

AOAC 935.37 (1935). Fat and Fat Number of Bread.

AOAC 939.03 (1939). Sugars (Reducing and Nonreducing) in Flour.

AOAC 945.37 (1945). Starch in Flour. Polarization Method.

AOAC 945.41 (1945). Calcium in Bread.

AOAC 950.36 (1950). Protein in Bread.

AOAC 975.14 (1975). Sugars in Bread.

AOAC 996.11 (2005). Starch (Total) in Cereal Products.

AOAC 997.06 (2005). Protein (Crude) in Wheat - Whole Grain Analysis

AOAC 999.10 (2005). Lead, Cadmium, Zinc, Copper and Iron in Foods.

Bhol, S., Lanka, D., Bosco, S.J.D. (2015). Quality Characteristics and Antioxidant Properties of Breads Incorporated with Pomegranate Whole Fruit Bagasse. Journal of Food Science and Technology, 53(3), 1717-1721.

Catană, M., Catană, L., Enuța, I., Asănică, A.C., Belc N. (2018). Bakery Products Fortified with Dried Fruits of Aronia melanocarpa. Scientific papers. Series B. Horticulture, 62: 693-701.

Collar, C., Conte, P. (2016). Lipid Dynamics in Blended Wheat and Non-wheat Flours Breadmaking Matrices: Impact on Fresh and Aged Composite Breads. Food Science and Technology International, 23(1), 24-35.

Kardum, N., Šavikin, K., Zdunić, G., Janković, T., Menković, N. (2018). Potential of chokeberry (Aronia melanocarpa L.) as a therapeutic food. In Holban A.M., Grumezescu A.M. (Eds.), Handbook of food bioengineering, Therapeutic Foods, Amsterdam: Academic Press, 209-237.

Denev, P., Kratchanova, M., Petrova, I., Klisurova, D., Georgiev, Y., Ognyanov, M., Yanakieva, I. (2018). Black Chokeberry (Aronia melanocarpa (Michx.) Elliot) Fruits and Functional Drinks Differ Significantly in Their Chemical Composition and Antioxidant Activity. Journal of Chemistry, 2018, ID 9574587, 1-11.

Dubois, V., Breton, S., Linder, M., Fanni, J., Parmentier, M. (2007). Fatty Acid Profiles of 80 Vegetable Oils with Regard to Their Nutritional Potential. European Journal of Lipid Science and Technology, 109(7), 710-732.

Dulf, F.V., Andrei, S., Bunea, A., Socaciu, C. (2012). Fatty Acid and Phytosterol Contents of Some Romanian Wild and Cultivated Berry Pomaces. Chemical Papers, 66(10), 925934.

Dziki, D., Różyło, R., Gawlik-Dziki, U., Świeca, M. (2014). Current Trends in the Enhancement of Antioxidant Activity of Wheat Bread by the Addition of Plant Materials Rich in Phenolic Compounds. Trends in Food Science and Technology, 40(1), 48-61.

Elson, C.E., Alfin-Slater, R.B. (1992). Tropical Oils: Nutritional and Scientific Issues. Critical Reviews in Food Science and Nutrition, 31(1-2), 79-102.

Eshak, N.S. (2016). Sensory Evaluation and Nutritional Value of Balady Flat Bread Supplemented with Banana Peels as a Natural Source of Dietary Fiber. Annals of Agricultural Sciences, 61 (2), 229-235.

Ezhilarasi, P.N., Indrani, D., Jena, B.S., Anandharamakrishnan, C. (2014). Microencapsulation of Garcinia Fruit Extract by Spray Drying and Its Effect on Bread Quality. Journal of the Science of Food and Agriculture, 94(6), 1116-1123.

Ferreira, M.S.L., Santos, M.C.P., Moro, T.M.A., Basto, G.J., Andrade, R.M.S., Gonçalves, É.C.B.A. (2013). Formulation and Characterization of Functional Foods Based on Fruit and Vegetable Residue Flour. Journal of Food Science and Technology, 52(2), 822-830.

Filipović, N., Šoronja-Simović, D., Filipović, J. (2006). Bread With Extruded Corn Products, Acta Agriculturae Serbica, 11(21), 29-36. 
Filipović, V., Filipović, J., Vučurović, V., Radovanović, V., Košutić, M., Novković, N., Vukelić, N. (2020). The Effect of Yeast Extract Addition on Bread Quality Parameters, Journal of the Serbian Chemical Society, 85(6), 737-750.

Gustinelli G., Eliasson L., Svelander C., Andlid T., Lundin l., Ahrné L., Alminger M. (2018). Supercritical Fluid Extraction of Berry Seeds: Chemical Composition and Antioxidant Activity, Journal of Food Quality, article ID 6046074

Hidalgo A., Brandolini A. (2011). Heat Damage of Water Biscuits from Einkorn, Durum and Bread Wheat Flours. Food Chemistry, 128, 471-478.

Hidalgo A., Tumbas Šaponjac V., Ćetković G., Šeregelj V., Čanadanović- Brunet J., Chiosa D., Brandolini A. (2019). Antioxidant Properties and Heat Damage of Water Biscuits Enriched with Sprouted Wheat and Barley. LWT - Food Science and Technology, 114, 108423.

Jayalakshmi T., Santhakumaran A. (2012). Statistical Normalization and Back Propagation for Classification. International Journal of Computer Theory and Engineering, 3, 1793-8201.

Juranović-Cindric I., Zeiner M., Mihajlov-Konanov D., Stingeder G. (2017). Inorganic Macro- and Micronutrients in "Superberries" Black Chokeberries (Aronia melanocarpa) and Related Teas. International Journal of Environmental Research and Public Health, 14, 539-548.

Kader, A.A., Barrett, D.M. (2004). Classification, Composition of Fruits and Postharvest Maintenance of Quality. In Barrett D.M., Somogyi L.P., Ramaswamy H.S. (Eds.), Processing Fruits: Science and Technology, CRC Press: Boca Raton, FL, USA, 3-22.

Karlović, Đ., Andrić, N. (1996). Kontrola kvaliteta semena uljarica. In Karlović Đ., Andrić N., Jakovljević J., Tanasković V., Berić B. (Eds.), Quality Control of Oilseeds, Faculty of Technology, Novi Sad, Federal Bureau of Standards, Belgrade, 35-46. (in Serbian with English abstract)

Kobus-Cisowska, J., Dziedziński, M., Szymanowska, D., Szczepaniak, O., Byczkiewicz, S., Telichowska, A., Szulc, P. (2020). The Effects of Morus alba L. Fortification on the Quality, Functional Properties and Sensory Attributes of Bread Stored under Refrigerated Conditions. Sustainability, 12(16), 6691.

Koshak, Z., Pokrashinskaya, A. (2020). Black Chokeberry Powder as an Improver for Pasta. Technology and Safety of Food Products, 14(1), 125-133.

Kulling, S.E., Rawel, H.M. (2008). Chokeberry (Aronia melanocarpa) - A Review on the Characteristic Components and Potential Health Effects. Planta Medica, 74(13), 1625-1634.

Kurtskova, V.G., Shishkina, E.E., Povituhina, Yu.V. (2005). Pechene s Poroshkom iz Chernoplodnoy Ryabinyi. Polzunovskiy Almanah, 1, 62-65. (in Russian with English abstract)

Mau, J.L., Lee, C.C., Yang, C.W., Chen, R.W., Zhang, Q.F., Lin, S.D. (2020). Physicochemical, Antioxidant and Sensory Characteristics of Bread Partially Substituted with Aerial Parts of Sweet Potato. LWT - Food Science and Technology, 117, 108602.

Mondragón, M., Mendoza-Martínez, A., Bello-Pérez, L., Peña, J. (2006). Viscoelastic Behavior of Nixtamalized Maize Starch Gels. Carbohydrate Polymers, 65 (3), 314-320.

Motta, C., Castanheira, I., Gonzales, G.B., Delgado, I., Torres, D., Santos, M., Matos, A.S. (2019). Impact of Cooking Methods and Malting on Amino Acids Content in Amaranth, Buckwheat and Quinoa. Journal of Food Composition and Analysis, 76, 58-65.

Nile, S.H., Park, S.W. (2014). Edible Berries: Bioactive Components and Their Effect on Human Health. Nutrition, 30(2), 134-144.
Parshutina, I.G., Baturina, N.A., Vlasova, M.V. (2012). Keksyi s Dobavkami Netraditsionnogo Rastitelnogo Syirya. Vestnik OrelGIET, 4, 169-174. (in Russian with English abstract).

Petković, M., Filipović, V., Filipović, J., Đurović, I., Miletić, N., Radovanović, J. (2020). Chemical, Antioxidative, and Sensory Characteristics of Wheat Bread Partially Substituted with Black Chokeberry (Aronia melanocarpa L.) Powder. Journal of Food Processing and Preservation, e15027.

Ranawana, V., Raikos, V., Campbell, F., Bestwick, C., Nicol, P., Milne, L., Duthie, G. (2016). Breads Fortified with Freezedried Vegetables: Quality and Nutritional Attributes. Part 1: Breads containing oil as an ingredient. Foods, 5(4), 19.

Richards, M.P., Hultin, H.O. (2000). Effect of $\mathrm{pH}$ on Lipid Oxidation using Trout Hemolysate as a Catalyst: A Possible Role for Deoxyhemoglobin. Journal of Agricultural and Food Chemistry, 48(8), 3141-3147.

Rutkowska, J., Antoniewska, A., Martinez-Pineda, M., Nawirska-Olszańska, A., Zbikowska, A., Baranowski, D. (2020). Black Chokeberry Fruit Polyphenols: a Valuable Addition to Reduce Lipid Oxidation of Muffins Containing Xylitol. Antioxidants, 9(5), 394.

Scott, R.W., Skirvin, R.M. (2007). Black Chokeberry (Aronia melanocarpa Michx.): A Semi-edible Fruit with no Pests. Journal of the American Pomological Society, 61(3), 135137.

Skupien, K., Oszmianski, J. (2007). The Effect of Mineral Fertilization on Nutritive Value and Biological Activity of Chokeberry Fruit. Agricultural and Food Science, 16(1), 46-55.

Sidor, A., Gramza-Michałowska, A. (2019). Black Chokeberry Aronia Melanocarpa L. - A Qualitative Composition, Phenolic Profile and Antioxidant Potential, Molecules, 24(20), 3710.

Sidor, A., Drożdżyńska, A., Gramza-Michałowska, A. (2019): Black Chokeberry (Aronia melanocarpa) and its Products as Potential Health-promoting Factors - An Overview. Trends in Food Science and Technology, 89, 45-60.

Shewry, P.R. (2010). Principles of Cereal Science and Technology. Journal of Cereal Science, 51, 415.

Sójka, M., Kołodziejczyk, K., Milala, J. (2013). Polyphenolic and Basic Chemical Composition of Black Chokeberry Industrial By-products. Industrial Crops and Products, 51, 77-86.

Šárka, E., Dvořáček, V. (2017): Waxy Starch as a Perspective Raw Material (A Review). Food Hydrocolloids, 69, 402409.

Šavikin, K., Zdunić, G., Janković, T., Gođevac, D., Stanojković, T., Pljevljakušić, D. (2014). Berry Fruit Teas: Phenolic Composition and Cytotoxic Activity. Food Research International, 62, 677-683.

Šnebergrová, J., Čižková, H., Neradová, E., Kapci, B., Rajchl, A., Voldřich, M. (2014). Variability of Characteristic Components of Aronia. Czech Journal of Food Science, 32(1), 25-30.

Tanaka, T., Tanaka, A. (2001). Chemical Components and Characteristics of Black Chokeberry. Nippon Shokuhin Kagaku Kogaku Kaishi, 48(8), 606-610.

Veraverbeke, S., Delcour, J.A. (2002). Wheat Protein Composition and Properties of Wheat Glutenin in Relation to Breadmaking Functionality. Critical Reviews in Food Science and Nutrition, 42(3), 179-208.

Zhang, D., Mu, T., Sun, H. (2017). Comparative Study of the Effect of Starches from Five Different Sources on the Rheological Properties of Gluten-free Model Doughs. Carbohydrate Polymers, 176, 345-355.

Zlatanov, M.D. (1999). Lipid Composition of Bulgarian Chokeberry, Black Currant and Rose Hip Seed Oils. Journal of the Science of Food and Agriculture, 79(12), 1620-1624. 